\title{
Pterosaurs as part of a spinosaur diet
}

\section{A rare fossilized action snapshot captures a mortal tussle with a hungry predator.}

A remarkable specimen has been discovered of an Early Cretaceous pterosaur that has a tooth embedded in one of its cervical vertebrae: the tooth has been identified as one from a spinosaurid theropod dinosaur. This fossil is direct evidence that spinosaurs included items other than fish in their diet.

The diet of spinosaurid theropods such as Baryonyx and Spinosaurus has been the subject of speculation ${ }^{1-3}$. Their peculiar elongated jaws, sinuous tooth row and crocodilelike teeth suggest that they were piscivores, a habit supported by the discovery of Lepidotes scales etched by gastric juices within the body cavity of the type specimen of Baryonyx walkeri, from the Wealden of Britain ${ }^{1}$. However, bones of a juvenile Iguanodon were also associated with the specimen, suggesting that Baryonyx might not have been exclusively a fish-eater. Baryonyx may also have been a scavenger ${ }^{4}$. Still, until now there has been no direct evidence to indicate what the diet of other spinosaurs could have been.

The specimen we describe here (Fig. 1; Wyoming Dinosaur Center, WDC-SFB001a,b,c), from the Early Cretaceous Santana Formation of northeastern Brazil, indicates that spinosaurs occasionally fed on pterosaurs, possibly during the course of scavenging activities. The specimen is part of a group of three pterosaur vertebrae enclosed in a nodule from the Romualdo Member of the Santana Formation ${ }^{5}$. The vertebrae are short and square-shaped in dorsal view, and are identified as cervical vertebrae ${ }^{6}$ numbers four to six of an ornithocheirid pterosaur, a
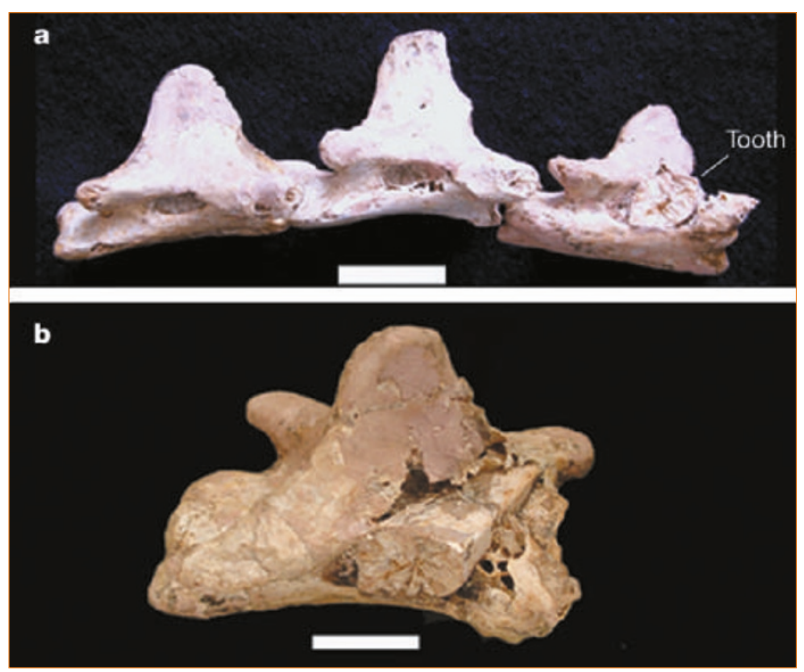

Figure 1 Cervical vertebrae of a pterosaur, with a dinosaur tooth embedded in one. a, Group of three cervical vertebrae (WDC-SFB-001a,b,c) of an ornithocheirid pterosaur from the Early Cretaceous Santana Formation of northeastern Brazil; right lateral view. The anteriormost vertebra is perforated by a spinosaur tooth. Scale bar: $20 \mathrm{~mm}$. $\mathbf{b}$, Close-up of pterosaur vertebra perforated by the spinosaur tooth, in dorsolateral view. Scale bar: $10 \mathrm{~mm}$. family that occurs frequently in the Santana Formation ${ }^{7}$. Their size indicates that they belonged to a creature with a wingspan of about 3.30 metres.

During the course of acid preparation of the nodule, we discovered that the anteriormost vertebra is perforated on the right side by a broken conical tooth (Fig. 1a). The tooth penetrates the vertebral centrum at the level of the anterior end of the pleurocoel, crosses the neural canal and damages the base of the neural arch, with its apex embedded in the left prezygapophysis (Fig. 1b). The thin, smooth enamel, straight crown, slightly compressed cross-section and lack of serrations on the lateral carinae show that the tooth is from a spinosaurid theropod.

Two spinosaurid taxa, Irritator challengeri and Angaturama limai, have been described from the Santana Formation ${ }^{3,8}$ (it is generally agreed that the latter is a junior synonym of the former). The tooth in the pterosaur vertebra is similar in every respect to the spinosaurid teeth previously described from the Santana Formation ${ }^{3,8}$.

The specimen is a rare instance of fossil 'behaviour': the tooth reached its present position when a spinosaurid bit into the neck of a pterosaur. As revealed by the presence of three associated cervical vertebrae, the neck must have been fresh and articulated when it was bitten; it was not swallowed and digested, because the vertebrae remain in articulation and lack evidence of etching by gastric juices. Despite their thin walls and hollow construction, the vertebrae must have been very resistant for the dinosaur tooth to break as it was biting them.

In what is the only previously known instance of dinosaur predation on a pterosaur - an azhdarchid tibia bitten by a troodontid from the Late Cretaceous of Alberta ${ }^{9}$ - a broken theropod tooth is similarly associated with a pterosaur bone. In the case described here, the pterosaur may have been caught on the wing or on the ground; although trackways reveal an unexpectedly high terrestrial velocity in some pterosaurs ${ }^{10}$, creatures with a large wingspan may have been vulnerable on the ground. But these options seem relatively unlikely and the scavenging of a pterosaur carcass on the shore of the lagoon in which the Santana Formation was deposited may be a more plausible explanation. Although the dinosaur did not swallow that part of the neck, this rare evidence of predation or scavenging shows that pterosaurs were part of the diet of spinosaurs, which we conclude were not strictly piscivorous.

Eric Buffetaut ${ }^{\star}$, David Martill $\dagger$,

François Escuilliéł

${ }^{\star}$ CNRS, 16 cour du Liégat, 75013 Paris, France e-mail:eric.buffetaut@wanadoo.fr

$\dagger$ School of Earth and Environmental Sciences,

University of Portsmouth, Portsmouth PO1 3QL, UK

\$Eldonia, 03800 Gannat, France

1. Charig, A. J. \& Milner, A. C. Bull. Nat. Hist. Mus. (Geol.) 53, 11-70 (1997).

2. Holz, T. R. Science 282, 1276-1277 (1998).

3. Sues, H.-D., Frey, E., Martill, D. M. \& Scott, D. M. J. Vert. Paleontol. 22, 535-547 (2002).

4. Kitchener, A. Nature 325, 114 (1987).

5. Martill, D. M. Fossils of the Santana and Crato Formations, Brazil (Palaeontological Association, London, 1993).

6. Wellnhofer, P. Palaeontographica A215, 43-101 (1991).

7. Kellner, A. W. A. \& Tomida, Y. Natl Sci. Mus. Monogr. 17, 1-135 (2000)

8. Kellner, A. W. A. \& Campos, D. de A. Neues Jb. Geol. Palaeontol. Abh. 199, 151-166 (1996).

9. Currie, P. J. \& Jacobsen, A. R. Can. J. Earth Sci. 32, 922-925 (1995).

10. Mazin, J. M., Billon-Bruyat J. P., Hantzpergue, P. \& Lafaurie, G. in Evolution and Palaeobiology of Pterosaurs (eds Buffetaut, E. \& Mazin, J. M.) 283-296 (Geol. Soc. Lond. Spec. Publ. 217, London, 2003)

Competing financial interests: declared none.

brief communications arising online

\section{www.nature.com/bca}

Biodiversity conservation: Uncertainty in predictions of extinction risk

W. Thuiller, M. B. Araújo, R. G. Pearson, R. J. Whittaker, L. Brotons, S. Lavorel (doi:10.1038/nature02716)

Biodiversity conservation: Effects of changes in climate and land use

L. B. Buckley, J. Roughgarden

(doi:10.1038/nature02717)

Biodiversity conservation: Climate change and extinction risk

J. Harte, A. Ostling, J. L. Green, A. Kinzig

(doi:10.1038/nature02718)

\section{Biodiversity conservation: Reply}

C. D. Thomas, S. E. Williams, A. Cameron, R. E. Green

M. Bakkenes, L. J. Beaumont, Y. C. Collingham,

B. F. N. Erasmus, M. Ferreira de Siqueira, A. Grainger, L. Hannah, L. Hughes, B. Huntley, A. S. van Jaarsveld,

G. F. Midgley, L. Miles, M. A. Ortega-Huerta,

A. T. Peterson, 0. L. Phillips (doi:10.1038/nature02719) 